\title{
Diseases of Pomegranate (Punica granatum) in Florida ${ }^{1}$
}

\author{
Katia V. Xavier, Achala N. KC, and Gary E. Vallad ${ }^{2}$
}

\section{Introduction}

California is the primary pomegranate-producing state in the United States, with approximately 33,000 acres in 2012 (NASS 2015). However, pomegranate production is becoming increasingly popular in the Southeast. At present, pomegranate in Florida remains an experimental fruit crop with approximately 200 acres from central to northern Florida. Florida's humid subtropical to tropical climate is favorable for not only pomegranate tree establishment, but also several diseases. As a consequence, a poorly managed orchard compromised by high disease levels can lead to yield losses of up to $90 \%$ (unpublished data).

\section{Pomegranate Diseases}

A series of field surveys conducted from 2014 to 2017 identified the most common and important pathogens causing disease on pomegranate in Florida (KC and Vallad 2016). Several fungal diseases were identified. Disease symptoms can range from leaves with spots of variable size and color, stems with blighting and dieback, and fruit with superficial to deep fruit lesions that can lead to fruit decay. Specific disease symptoms vary depending on the causal pathogen. Furthermore, mixed infections of leaves and fruit by several fungal pathogens are fairly common. The most common diseases associated with pomegranate in Florida are detailed below.

\section{Anthracnose}

Anthracnose is a disease caused by species of Colletotrichum and affects multiple fruit crops (Peres et al. 2008,
Polashock et al. 2005, MacKenzie et al. 2007, MacKenzie et al. 2009). Our surveys showed that anthracnose is one of the most important diseases of pomegranate in Florida. The most common symptoms are spots, blotches, defoliation, shoot blight, twig cankers, and dieback. Fruit symptoms consist of sunken lesions in which the pathogen produces massive amounts of spores that may be visible to the naked eye as orange, slimy masses.

On pomegranate, the disease is caused by several species of Colletotrichum that are grouped within two major species complexes, the $C$. acutatum species complex and the $C$. gloeosporioides species complex (Xavier et al. 2019a). By late May to June when the rainy season begins in Florida, anthracnose symptoms are typically observed on the calyx of green fruit as hard, dark brown to black necrotic lesions (Figure 1). After prolonged summer rains, the lesions on ripening fruit appear as randomly scattered, irregularly shaped rotted spots. These fruit spots are sunken and often progress through the rind and arils, leading to fruit decay (Figure 2). Gray to orange masses of spores often become visible on lesions of either green or ripe fruit when the weather conditions remain wet and humid for prolonged periods of time.

On leaves, anthracnose causes irregular brown spots (Figure 3). The incidence of leaf spots increases with prolonged rain events and results in severe defoliation. The pathogen also infects young shoots and causes stem tip dieback on new growth (Figure 4).

1. This document is PP349, one of a series of the Plant Pathology Department, UF/IFAS Extension. Original publication date October 2019. Visit the EDIS website at https://edis.ifas.ufl.edu for the currently supported version of this publication.

2. Katia V. Xavier, postdoctoral researcher; Achala N. KC, postdoctoral researcher; and Gary E. Vallad, associate professor, Plant Pathology Department, UF/ IFAS Gulf Coast Research and Education Center, Wimauma, FL 33598.

The Institute of Food and Agricultural Sciences (IFAS) is an Equal Opportunity Institution authorized to provide research, educational information and other services

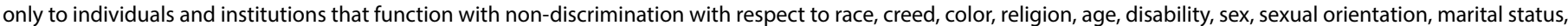

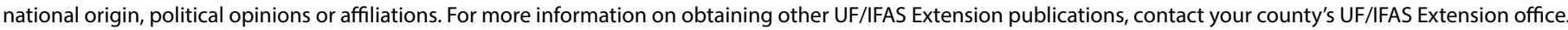
U.S. Department of Agriculture, UF/IFAS Extension Service, University of Florida, IFAS, Florida A \& M University Cooperative Extension Program, and Boards of County Commissioners Cooperating. Nick T. Place, dean for UF/IFAS Extension. 


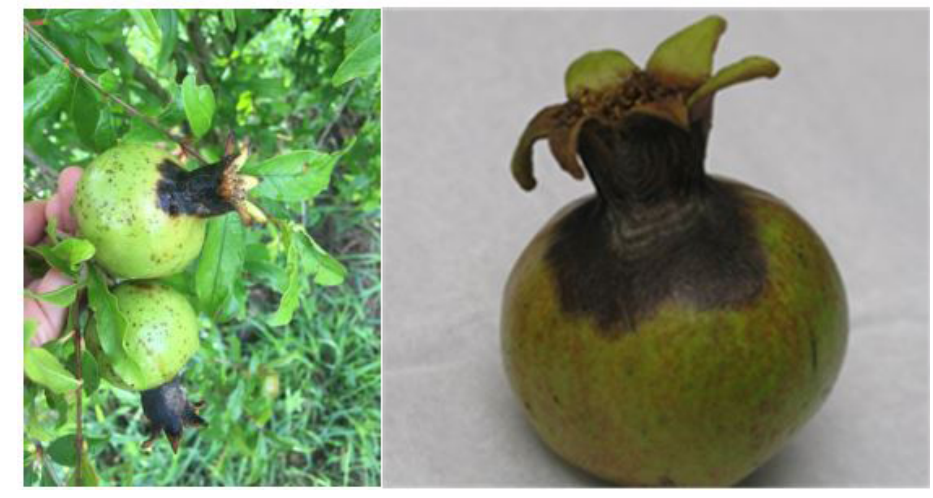

Figure 1. Fruit tip dieback of pomegranate caused by Colletotrichum spp.

Credits: K. V. Xavier

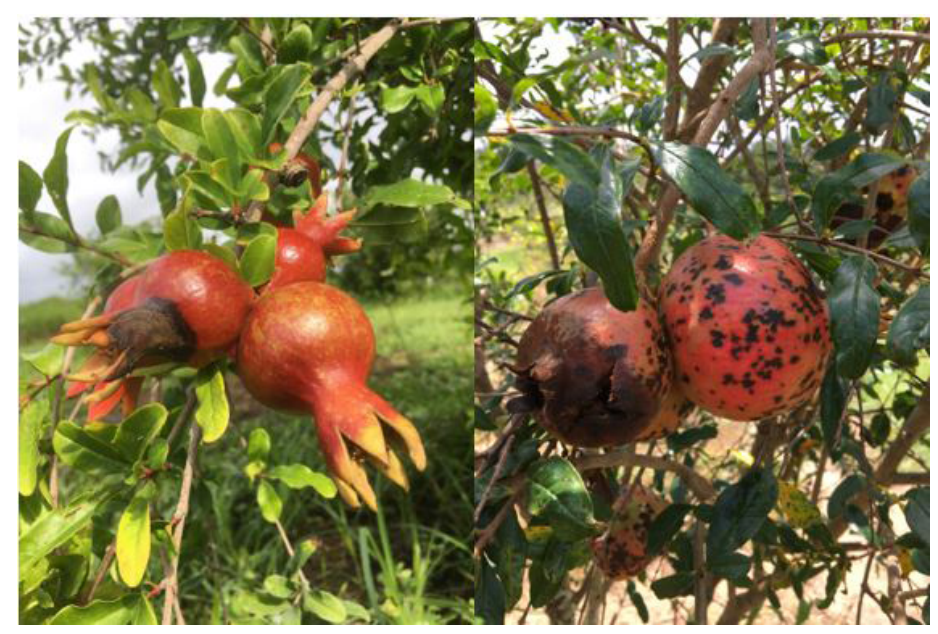

Figure 2. Fruit rot of pomegranate caused by Colletotrichum spp. Credits: K. V. Xavier

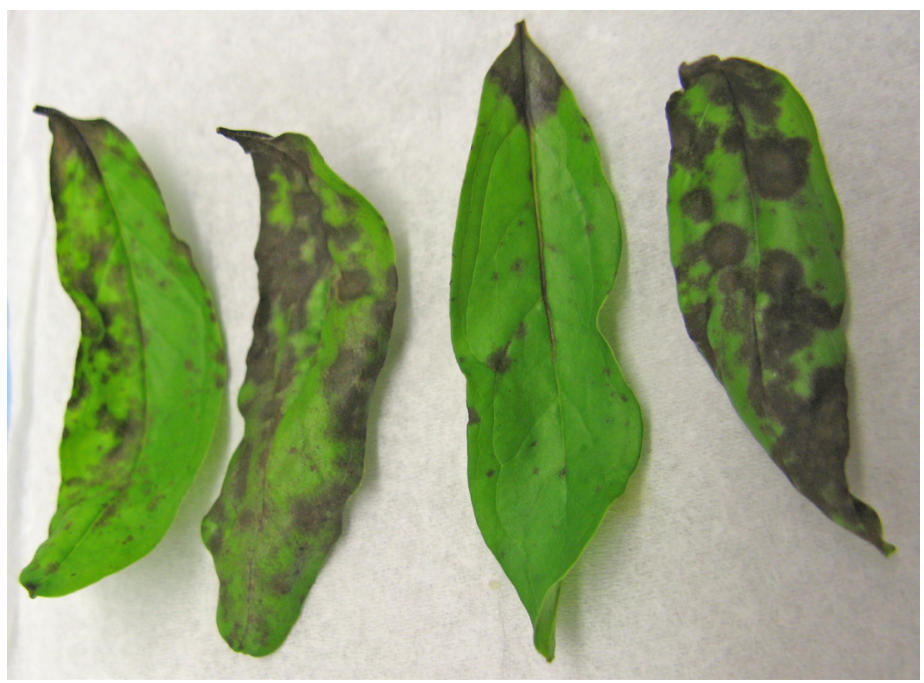

Figure 3. Anthracnose leaf spot of pomegranate caused by Colletotrichum spp.

Credits: K. V. Xavier

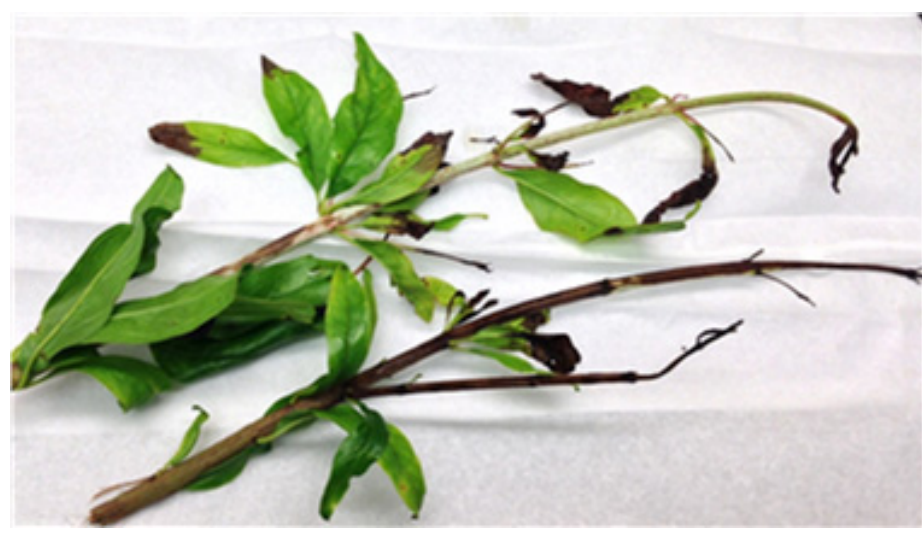

Figure 4. Stem tip dieback of pomegranate caused by Colletotrichum spp.

Credits: K. V. Xavier

\section{Leaf and Fruit Spots Caused by Pseudocercospora punicae}

Pseudocercospora punicae causes another very common disease on pomegranate in Florida, which has also been associated with leaf or fruit spots. On the leaves, the symptoms start as small $(0.1-0.3 \mathrm{~cm})$, irregularly shaped dark brown lesions. These lesions can expand $(0.5-1.2 \mathrm{~cm})$ and develop a distinct, dark brown margin with gray coloration. Sometimes the lesions are large enough to observe concentric rings of alternating dark and light gray in the lesion center (Figure 5). A greenish halo often forms around the lesions and becomes very pronounced as the leaves yellow from chlorosis. Eventually leaves senesce, leading to severe defoliation, which can reduce yields. Symptoms on the fruit are small irregular black lesions that can later coalesce into bigger blotches (Figure 5). Lesions caused by P. punicae on the fruits are superficial only, contrary to Colletotrichum and other fungal pathogens, which affect the rind and arils. The symptoms on leaves and fruits can vary among the different pomegranate varieties.

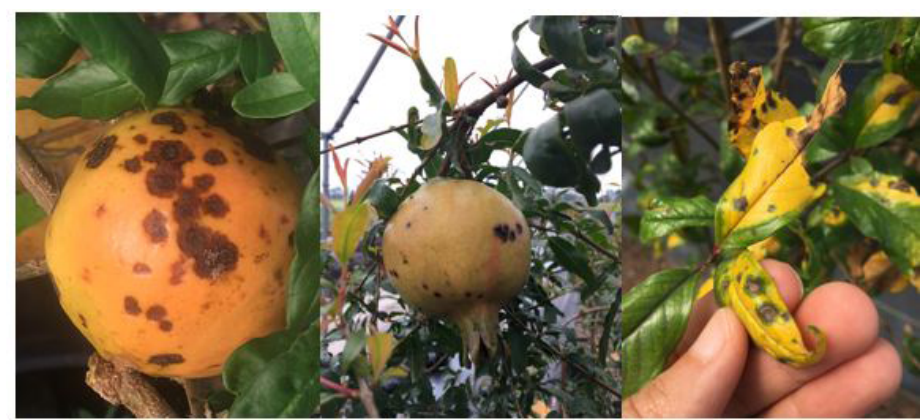

Figure 5. Fruit and leaf spot caused by P. punicae. Credits: K. V. Xavier 


\section{Dwiroopa punicae}

Dwiroopa punicae, a novel fungal species belonging to the order Diaporthales, is also associated with leaf spot and fruit rot on pomegranate (Xavier et al. 2019b). Leaf spots associated with this fungus are oval and brown, vary from 0.1 to $1.5 \mathrm{~cm}$ in diameter, and appear scattered on the leaf surface (Figure 6). Abundant black pycnidia (resembling little black dots) become visible on the lesion center (Figure 6 , last on the right). The symptoms caused by D. punicae on the fruit start as small brown lesions on the fruit calyx at different stages (Figure 7).

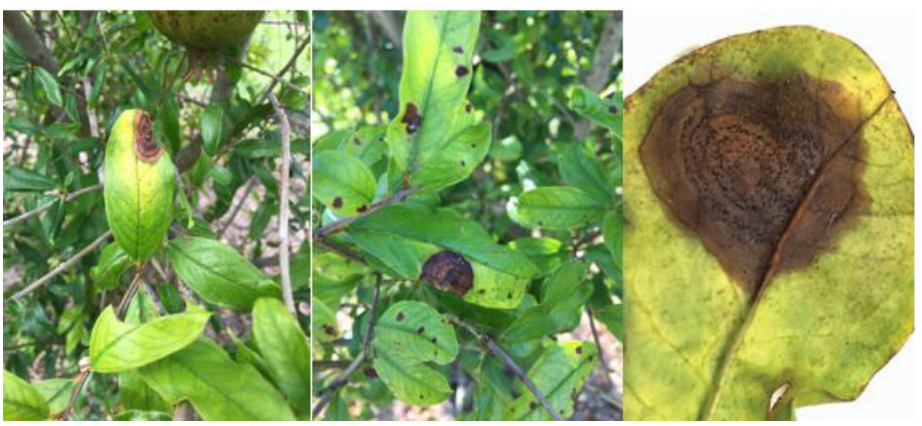

Figure 6. Leaf spots caused by Dwiroopa punicae with a close up on the lesion showing pycnidia as black dots on its center.

Credits: K. V. Xavier
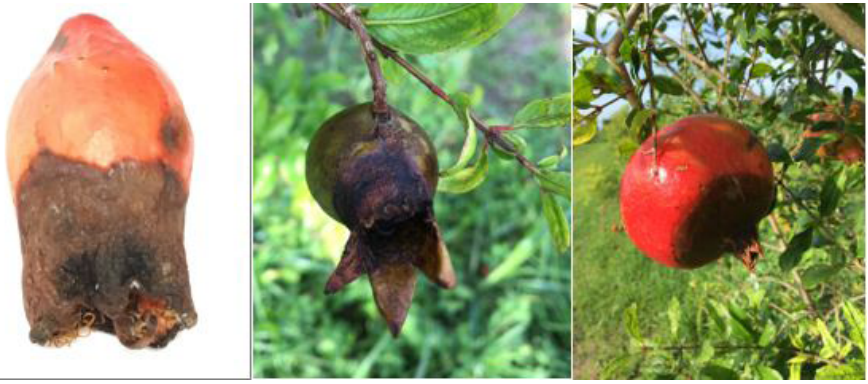

Figure 7. Pomegranate fruits at several stages infected by D. punicae. Credits: K. V. Xavier

Lesions increase in size and become black due to the pathogen's abundant sporulation on the fruit surface (Figure 7). Rot caused by D. punicae affects the arils and often causes premature fruit drop. Unlike those lesions caused by Colletotrichum spp., the lesions caused by $D$. punicae are not sunken.

\section{Botryosphaeria Stem Canker and Shoot Blight}

Two pathogens in the Botryosphaeriaceae family, Neofusicoccum parvum and Lasiodiplodia theobromae, cause stem-canker and shoot-blight diseases on pomegranate. The symptoms start as small brown lesions on succulent stems. Artificially infected stems develop blight-like symptoms three months after inoculation (Figure 8, bottom right). The lesions expand and develop into large swollen cankers with deep cracks and numerous fruiting bodies a year after infection (Figure 8). Stems are slowly girdled and the tree dies after one to two years. Numerous fruiting bodies become visible on the surface of infected stems (Figure 8, bottom and upper left).
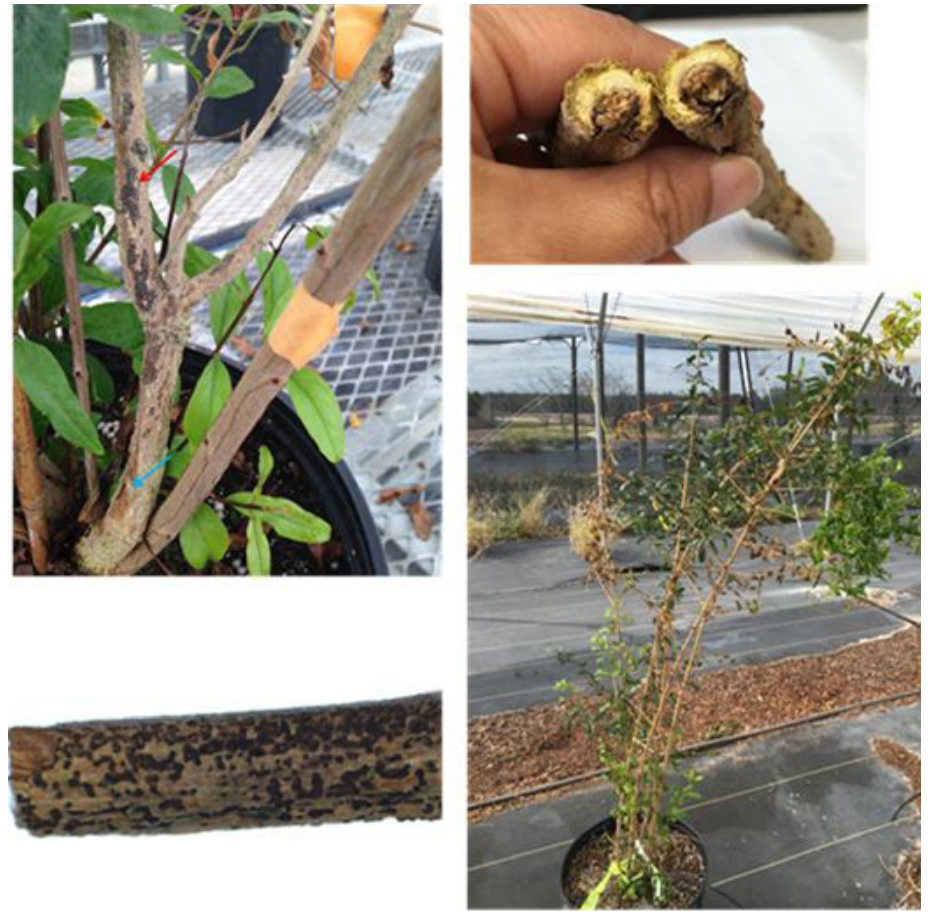

Figure 8. Botryosphaeria stem canker and shoot blight of pomegranate caused by Neofusicoccum parvum and Lasiodiplodia theobromae.

Credits: A. N. KC

\section{Fruit Rot and Mummification}

Fruit rot is a serious problem of pomegranate and can result in more than $80 \%$ fruit loss in Florida. In addition to fruit rots caused by Colletotrichum spp. and D. punicae, a third fungal pathogen, Pilidiella granati, is often isolated from rotten fruit. The fruit surface starts to turn brown, with the rot progressing into the rinds and to the arils. The fruit start to decay, and abundant black pycnidia become visible on the fruit surface as small raised black dots (Figure 9). Stem blight and leaf spot symptoms may also occur. Leaf spots caused by P. granati have concentric rings of pycnidia on the lesion. Toward the end of the growing season, fruit infected by P. granati become dry and mummified. Nearly $50 \%$ of these mummified fruit drop, while the rest remain attached to the tree (Figure 10). Multiple pathogens are often isolated from these mummified fruit, including Colletotrichum spp., N. parvum, L. theobromae, D. punicae, and P. granati. These observations reinforce the need to remove all mummified and rotted fruit from orchards during and between seasons to limit the potential spread and carryover of inoculum. The importance of orchard sanitation in disease management is covered in the next section. 


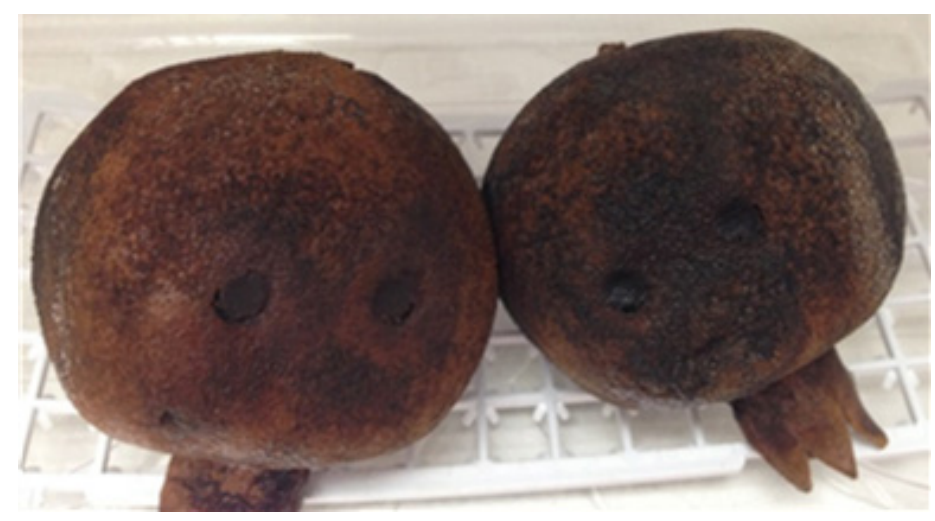

Figure 9. Fruit rot caused by Pilidiella granati. Black dots are the pycnidia on fruit surface.

Credits: A. N. KC

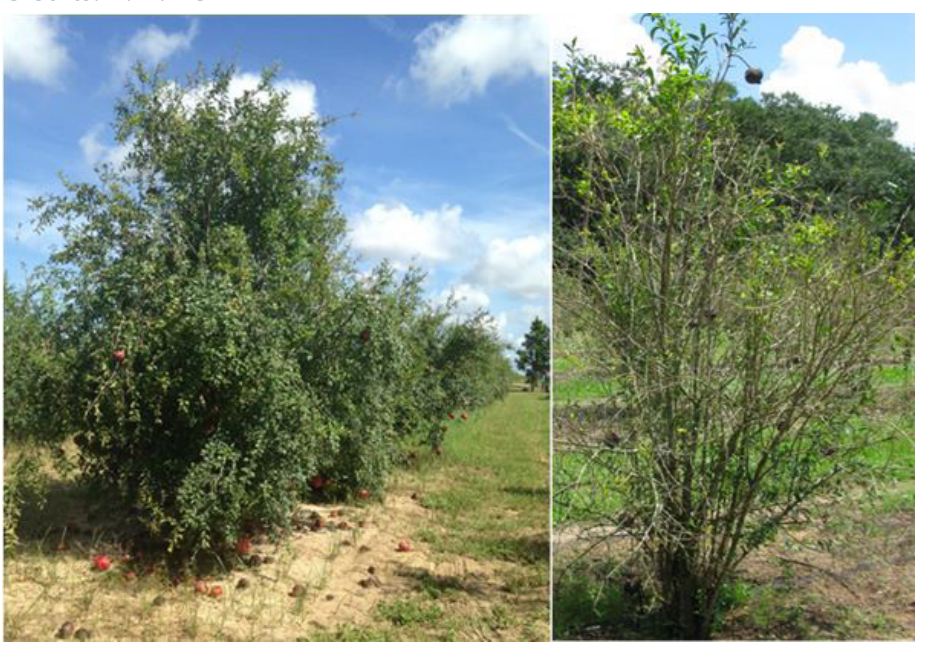

Figure 10. Fruit drop, fruit mummification, and defoliation of pomegrante in Florida orchards caused by combination of different pathogen species.

Credits: A. N. KC

\section{Disease Management}

Disease management is essential to successful pomegranate production in Florida. Integrating cultural practices with chemical control and resistant varieties will be crucial for sustainable disease management and successful production. Thorough knowledge of orchard design and site selection, planting density, variety selection, and past disease problems is important in establishing a new orchard. Detailed information on starting and managing a pomegranate enterprise is available on a website (http://www.crec.ifas. ufl.edu/extension/pomegranates) developed by Dr. Bill Castle, professor emeritus, UF/IFAS Horticultural Sciences Department.

Weed management, irrigation, and fertility management are important in maintaining plant vigor. Based on a general survey, pomegranate orchards that maintained proper weed and nutrient management had relatively lower disease pressure compared to unmanaged orchards. Weeds compete with the main crop for resources such as water and nutrients, and they may serve as alternative hosts for some plant pathogens. Similarly, regular scouting and pest identification is important to understand the biology of both the pest and the pomegranate tree throughout the year. This is important to help recognize the susceptible developmental stages of the pomegranate tree, which further assists in the selection and timing of management practices, including pesticide applications. A list of pesticides labeled for use in pomegranate in Florida is available at http://www.crec.ifas. ufl.edu/extension/pomegranates/pesticides.shtml. Fungicides currently labelled for pomegranate are ineffective against the fungal pathogens reviewed in this publication. However, several products are currently under evaluation by the EPA for use on pomegranate. Recommendations will be forthcoming as effective commercial products become available.

Field sanitation is an integral part of any diseasemanagement strategy because it helps reduce the level of pathogen inoculum present in the field, which in turn can delay or even prevent disease development. Sanitation is best achieved by clearing leaf litter, fruit, and diseased stems from orchards. Especially during the winter when many trees go dormant and lose their leaves, it is very important to clear leaf debris from around trees that may be harboring pathogens from the previous season. Infected leaves, stems, and fruit should be removed from the orchard to a safe distance and burned as permitted by local ordinances. If burning is not an option, the debris should be buried or covered and composted.

It is also important to inspect trees for diseased branches. The pathogens Neofusicoccum parvum and Lasiodiplodia theobromae were frequently isolated from pedicel (a specialized stem that attaches the fruit to the branch) samples. Therefore, pruning diseased branches and remaining pedicels should help minimize the carryover of several pathogens. Growers need to be mindful of moisture when pruning diseased branches. Prune trees during dry weather and ensure cuts are made at an angle to allow water to drain from wood surfaces. Although no specific pruning guidelines are available for pomegranate in Florida, readers can refer to the guidelines in HS1111, Training and Pruning Florida Peaches, Nectarines, and Plums (https://edis.ifas. ufl.edu/hs365). It is best to prune trees in the winter when spore production is low and the plants are dormant, or late in fall when wounds are less susceptible to infection and heal more rapidly. Similarly, equipment that comes into contact with diseased tissues should be sanitized using an approved sanitizer or other approved disinfectant between trees. Readers can refer to https://www.freshfromflorida. com/content/download/9901/135674/decontamination.pdf 
for a list of products approved for citrus, which should also be effective against most fungal agents on pomegranate.

The use of resistant varieties is one of the most economical and sustainable practices for disease management. Currently, over 100 pomegranate cultivars are under evaluation for various traits at UF. In addition, more than 2000 breeding lines will be screened for disease resistance and other economically important traits. Available trait information for pomegranate cultivars assessed through efforts of UF and the Florida Pomegranate Association are available at http://www.crec.ifas.ufl.edu/extension/pomegranates/. Advancing the development of new pomegranate cultivars adapted to the climatic conditions and disease pressures inherent to the Southeast will surely assist sustainable pomegranate production into the future.

\section{References}

KC, A., and G. Vallad. "Monitoring Pomegranate Pathogens Towards Developing Effective Disease Management Program." Phytopathology 106(12): 94.

Mackenzie, S., T. Seijo, D. Legard, L. Timmer, and N. Peres. 2007. "Selection for Pathogenicity to Strawberry in Populations of Colletotrichum gloeosporioides from Native Plants." Phytopathology 97(9): 1130-1140.

MacKenzie, S. J., N. A. Peres, M. P. Barquero, L. F. Arauz, \& L. W. Timmer. 2009. "Host Range and Genetic Relatedness of Colletotrichum acutatum Isolates from Fruit Crops and Leatherleaf Fern in Florida." Phytopathology 99(5): 620-631.

National Agricultural Statistics Service. 2015. "Agricultural Statistics 2015.” Accessed 12/19/17. https://www.nass.usda. gov/Publications/Ag_Statistics/2015/index.php.

Peres, N., S. Mackenzie, T. Peever, and L. Timmer. 2008. "Postbloom Fruit Drop of Citrus and Key Lime Anthracnose Are Caused by Distinct Phylogenetic Lineages of Colletotrichum acutatum." Phytopathology 98(3): 345-352.

Polashock, J. J., M. K. Ehlenfeldt, A. W. Stretch, and M. Kramer. 2005. "Anthracnose Fruit Rot Resistance in Blueberry Cultivars." Plant Disease 89(1): 33-38.

Xavier, K. V., A. N. KC, N. A. Peres, Z. Deng, W. Castle, W. Lovett, and G. E. Vallad. 2019a. "Characterization of Colletotrichum species causing anthracnose of pomegranate in the southeastern U.S." Plant Disease. https://doi. org/10.1094/PDIS-03-19-0598-RE.
Xavier, K. V., A. N. KC, P. W. Crous, J. Z. Groenewald, and G. E. Vallad. 2019b. "Dwiroopa punicae sp. nov. (Dwiroopaceae fam. nov., Diaporthales), associated with leaf spot and fruit rot of pomegranate (Punica granatum)." Fungal Systematics and Evolution 4(1): 33-41. 